\title{
Wine and Words: A Trilingual Wine Dictionary for South Africa*
}

\author{
Michele F. van der Merwe, Faculty of Education and Social Sciences, Cape \\ Peninsula University of Technology, Wellington Campus, Wellington, \\ Republic of South Africa (vandermerwem@cput.ac.za)
}

\begin{abstract}
The South African wine industry identified the need for a special-field on-line dictionary on viticulture and oenology in Afrikaans, English and isiXhosa. The dictionary provides information on wine terminology as well as linguistic information on the use of such terminology. The purpose of this article is to give a description of the project. The process of compiling the dictionary is described, from the co-operation between the wine industry and lexicographers to the intended target users and the choice of languages of the dictionary. Functions of the dictionary are discussed, with reference to specific user situations, namely text production, text reception and translation. A system of labels has been designed for the dictionary and its benefit for the user is explained. In assisting the user to make an informed choice of a term, the notion of proscriptiveness has been followed in the presentation of information in the wine dictionary.
\end{abstract}

Keywords: TRILINGUAL WINE DICTIONARY, SPECIALISED LEXICOGRAPHY, VITICULTURE AND OENOLOGY TERMS, ON-LINE DICTIONARY, TARGET USERS, USER SITUATIONS, FUNCTIONS, TEXT RECEPTION, TEXT PRODUCTION, TRANSLATION, LABELS, ENCYCLOPEDIC KNOWLEDGE, LINGUISTIC KNOWLEDGE, PROSCRIPTION

Opsomming: Wyn en woorde: 'n Drietalige Wynwoordeboek vir SuidAfrika. Die Suid-Afrikaanse wynbedryf het die behoefte aan 'n aanlynvakwoordeboek oor wynen wingerdkunde in Afrikaans, Engels en isiXhosa geïdentifiseer. Die woordeboek verskaf inligting oor wynterminologie, sowel as taalkundige inligting oor die gebruik van sulke terminologie. Die doel van hierdie artikel is om ' $n$ beskrywing van die projek te gee. Die samestellingsproses van die woordeboek word beskryf, vanaf die samewerking tussen die wynbedryf en die leksikograwe, tot die voorgestelde teikengebruikers en die keuse van die tale van die woordeboek. Funksies van die woordeboek word bespreek, met verwysing na spesifieke gebruikersituasies, naamlik teksproduksie, teksresepsie en vertaling. 'n Etiketstelsel is vir die woordeboek ontwerp en die voordeel daarvan vir die gebruiker word verduidelik. Ten einde die gebruiker te help om 'n ingeligte keuse van 'n term te maak, is die begrip van proskripsie gevolg by die aanbieding van die inligting in die woordeboek.

Sleutelwoorde: DRIETALIGE WYNWOORDEBOEK, GESPESIALISEERDE LEKSIKOGRA-

* This article was presented as a paper at the Twelfth International Conference of the African Association for Lexicography, organised by the Tshwane University of Technology in collaboration with the IsiNdebele National Lexicography Unit, at the Soshanguve Campus, Pretoria, Republic of South Africa, 27-29 June 2007.

Submitted for Lexikos 18 (AFRILEX-reeks/series 18: 2008) 337-348 
FIE, WINGERD- EN WYNKUNDETERME, AANLYNWOORDEBOEK, TEIKENGEBRUIKERS, GEBRUIKERSITUASIES, FUNKSIES, TEKSRESEPSIE, TEKSPRODUKSIE, VERTALING, ETIKETTE, ENSIKLOPEDIESE INLIGTING, TAALKUNDIGE INLIGTING, PROSKRIPSIE

\section{Why a dictionary of wine terms?}

The need for a special-field dictionary of wine terms was identified by the wine industry in 2005. Already in 1973, a South African Wine Dictionary was compiled by the Language Services Bureau with Afrikaans and English as language pairs. Since this dictionary is merely a list of terms in the source language, accompanied by their target-language equivalents, it is of little assistance to the present-day user. In this Wine Dictionary, no explanations of and no syntactic information on terms are provided. Many of the terms had to be replaced by new ones as some of them were no longer in use in the wine industry, for example, keg. The rapid development in the field of wine biotechnology necessitated the creation of many new terms to account for new inventions in the field, for example, biofilm, biogenesis, bioinformatics and biosensor. Being dated, the Wine Dictionary could not make provision for new terms to describe developments in any field relating to the wine industry for the last 35 years. Providing neither semantic nor grammatical information, such a dictionary at best confirms the expert's own assumptions, but laypeople and semi-experts alike will find it unsuitable for text reception and translation purposes. The 1973 dictionary, containing only a restricted number of terms, is not widely known among wine industry members, and, as it is out of print, it was decided to compile a new wine dictionary.

The South African Trilingual Wine Dictionary (SATWD) makes provision for data on viticulture and oenology. The subject field viticulture includes organic cultivation and production, cultivation, soil science, plant biotechnology, vine viruses, plant protection and plant improvement. The subject field oenology includes production technology, bottling, packaging and distribution, byproduct handling and waste product handling, brandy and distilling, and microbiology. In short, the SATWD transfers information on the physiology of the vine, the fruit of the vine as well as the wine-making process.

It was decided to use Trados Multiterm to create an electronic dictionary with the advantage of being cost-effective to the industry. On completion the database would be available on-line to the wine industry and to the general public. Access would be via two websites, namely the Sawis Library website and the Winetech website.

Another advantage of an on-line dictionary would be to manage data effectively, by updating it on a continuous basis, adding or deleting terms as required. It could prove to be very effective, especially in a field like the wine industry where there is so much development with new concepts gaining currency and subsequently new terms being created on a regular basis.

After the launch of the SATWD on-line, the compilers will hopefully 
receive continuous feedback from the industry. Users, be they laypeople or subject-field specialists, could contribute to the dynamism of the dictionary by continuous communication on-line. The advantage of user participation would be the input on translations in Afrikaans and isiXhosa, as well as definitions of terms. Provided that sufficient comments and feedback are received, it could lead to the improvement of the dictionary by reflecting the views of users and their use of terms and translations.

The purpose of the article is to describe the project by sketching the initialisation of the project, describing the purpose and function of the dictionary, and referring to other special-field dictionaries. The extensive labelling system and proscriptive treatment of terms are also discussed.

\section{Co-operation between the wine industry and lexicographers}

Winetech, coordinator of research, training and technology in the wine industry, and Sawis, responsible for the collection, processing and dissemination of industry information, jointly fund the project. This is a first for the wine industry to be engaged in a lexicographic endeavour. There are examples of agricultural industry boards involved in the compiling of special-field dictionaries in South Africa. In 1958 Vertalende en Verklarende Woordeboek vir die Wolbedryf (ed. A.J. Hanekom) was published by the South African Wool Board and in 1990 Directory of Cotton Terms for South Africa (ed. K.W. Sanderson) was produced by the South African Cotton Board.

The Preface to the Encyclopedic Dictionary of Gene Technology (Bergenholtz and Kaufmann 1998: 5) rightly states: 'No technically related dictionary article shall be designed solely by a linguistic nor by a technical expert. Only the interdisciplinary co-operation can produce a reference work which can be both lexicographically and technically satisfactory.' The SATWD is a practical example of such co-operation and consultation. Lexicographic planning was done by a lexicographer, resulting in a dictionary plan which was then submitted to subject-field specialists, as well as industry bodies. Input was received from various subject-field specialists, mostly academics and the industry body Winetech. During the compilation of the SATWD there was continuous consultation between the lexicographer, information specialist and subject-field specialists. Consultation related to issues such as the inclusion of terms, the translation of terms, definitions of terms and the use of different subject labels. Since the SATWD covers such a wide range of subject fields within the field of viticulture and oenology, it was essential to consult with experts on these various fields.

\section{Choosing the languages}

The wine industry in South Africa consists of three geographical units, namely the Western Cape, the Northern Cape and Kwazulu-Natal. Since most of the 
wine-making activities are based in the Western and the Northern Cape, it was decided to focus on the official languages of these provinces, namely Afrikaans, isiXhosa and English. The SATWD seeks to fulfil the language needs of users of the designated language groups regarding wine terminology in South Africa. Many Afrikaans-speaking farmers are involved in the wine industry. However, there is a growing need also for isiXhosa speakers to join the industry. With more emphasis on the training and education of emerging farmers the development of isiXhosa wine terminology is therefore essential.

The pedagogical aspect of the dictionary is important for it can be a useful tool in the training of Afrikaans, English and isiXhosa students at tertiary level. There is a need for students to be able to use the technical terminology of the wine industry, be that at university or agricultural college level. The SATWD can serve as an important communication tool in the training of especially isiXhosa students, since a large number of words were translated into isiXhosa during the compilation of the SATWD. This is the first time that isiXhosa would feature as a member of a language pair in a specialised dictionary of wine terminology.

It is assumed that mother-tongue education could play a major role in providing access to science and technology. Such a multilingual specialised dictionary could serve as an important learning aid during tertiary education, be that for lecturers to compile course material for students or for students to look up translations and definitions of terms. Functions of the dictionary to be used in these instances would be those of text production, translation and text reception.

Another target group of users to benefit from the pedagogical aspect of the SATWD would be people belonging to wine circles wishing to be trained in organoleptic evaluations of wine. According to Brochet and Dubourdieu (2001: 187), wine is one of the more often described foods, wine literature being widespread with numerous journals, books and reviews presented to the public and to experts or professionals. Those who fail to describe wine flavours, unable to speak about its taste in a professional manner, are usually considered as 'not knowing anything about wine.' Winemakers, professional critics, oenologists, and amateurs have developed a language or vocabulary which describes the sensory properties of wine. This is used to exchange information on sensory data and to analyze this information. The SATWD contains a large number of terms for the organoleptic evaluation of wine, and especially in the case of Afrikaans and isiXhosa, the vocabulary of these languages has definitely been extended. The Afrikaans wine magazine Fynproe has also contributed greatly to the extension of the Afrikaans wine-tasting vocabulary.

Being an on-line dictionary, the SATWD can contribute indefinitely to the extension of languages, with the possibility of including other indigenous languages, like isiZulu (Kwazulu-Natal forms another geographical unit of the wine industry) as well as the languages of the traditional European wine-producing countries like France, Spain and Germany. 


\section{Identifying the target users}

In August 2005, a dictionary plan was drawn up and target-users were identified. Bergenholtz and Kaufmann (1997: 101) distinguish three groups of targetusers for LSP dictionaries: laypeople, semi-experts, and experts. Most of the target-users of the SATWD could be described as semi-experts, having a higher level of knowledge than laypeople. They include viticulturists, vintners, winefarmers, wine-lovers, wine-writers, wine-marketers, wine-consultants, wine and viticulture lecturers and students, extension officers and information officers, as well as translators. As this user-group can be described as heterogeneous, provision needs to be made for covering problems relating to the subject field in language comprehensible to laypeople and semi-experts alike.

Excellent provision was made for such a heterogenous group in the Encyclopedic Dictionary of Gene Technology (EDGT) (Kaufmann and Bergenholtz 1998: 8) where the compilers opted for an encyclopaedic dictionary instead of the traditional reference work providing encyclopaedic data or conveying linguistic data. In the case of one or more subject fields, the former are called specialised encyclopaedias and the latter specialised dictionaries. This dictionary provides factual data and specialised linguistic data on gene technology. The aim of the reference work is to be an 'aid to understand purely encyclopaedic relationships and an aid in the communications of topics on gene technology'. One of the aids implemented in this dictionary is a very long introduction, called the encyclopaedic section on the subject of gene technology. It forms the subject-field component of the dictionary, giving an overview of the systematics forming the basis of gene technology. This overview can be read as a small work in its own right, completely independently from the dictionary, to obtain basic information on the technical basis of molecular biology and gene technology. In a dictionary context, it is intended as an aid for those readers requiring a concise account.

A similar subject-field component should be compiled in Afrikaans, English and isiXhosa for the SATWD. Such an introduction can feature data on viticulture, for example the physiology of the vine, and data on oenology, for example the wine-making process, as well as the appreciation of wine. Users would have access to data on the different stages of the wine-making process. They could read it as a background or they could use it as reference when looking up specific information regarding a term or a definition encountered in the dictionary. The subject-field component would then serve as an integrated text in the dictionary which the user can consult when, having looked up the meaning of a term in the dictionary, the need arises to gain more information on the specific term.

\section{Functions of the SATWD}

As lexicographers become more aware of the notion of the user-perspective 
and try to employ user-orientated techniques in dictionaries, the typology of traditional dictionaries change. It is therefore not strange to find more dictionaries with explanatory as well as translational qualities. Change has also occurred in special-field dictionaries, of which the Encyclopedic Dictionary of Gene Technology (Kaufmann and Bergenholtz 1998) is a good example.

Tarp (2005: 10) describes the EDGT as a two-way, bidirectional and multifunctional dictionary. Eight main user situations for which the dictionary is designed are specified. These are:

(a) the reception of Spanish texts,

(b) the production of Spanish texts,

(c) the reception of English texts,

(d) the production of English texts,

(e) the translation from Spanish into English,

(f) the translation from English into Spanish,

(g) the information on subjects within molecular biology, and

(h) the indirect text-related information about Spanish and/or English molecular biology language usage.

The functional theory (Tarp 2005: 7) concentrates on the extra-lexicographic user situations of which two main types can be distinguished: the communication-related and cognitive-related. The first is related to communicative situations such as L1 and L2 text production, L1 and L2 text reception, as well as $\mathrm{L} 1 \rightarrow \mathrm{L} 2$ translation and $\mathrm{L} 2 \rightarrow \mathrm{L} 1$ translation. The second is related to non-communicative situations where users want or need a certain kind of knowledge, for example linguistic, general encyclopaedic or specialised knowledge.

An example of two entries in the EDGT is provided. A user could look up the term gene pool in the English section and be given the translation in Spanish, as well as a definition of the term gene pool. The user would be able to use the dictionary for translation, text production in English and text reception in English. In the case of gene preservation, the Spanish translation is provided and the user would be able to use the dictionary for translation.

gene pool pool $m$ genico

A gene pool is the total number of genes present in a population at a certain time The addition of the second $X$-chromosome gene must have occurred sometime after the separation of South America and Africa, and hence of the gene pools of the New and old World monkeys, some 40 million years ago.

gene preservation preservacion $f$ de genes

It is difficult to typologise the SATWD according to traditional dictionary categories. It can at best be described as a multifunctional dictionary, having explanatory as well as translational qualities. It is aimed at text reception, text production and text translation. A translation of a term is supplied in two languages, e.g. Afrikaans and isiXhosa.

The purpose of the SATWD would be firstly to supply data on the subject 
fields viticulture and oenology, as well as linguistic information on terms.

The explanatory part of the dictionary includes a definition of the term in English, a subject label and an indication of the word class/part of speech. Word class of terms is provided, since that is the only syntactical information presented to the user as no illustrative material is given, as shown by the following two examples from the SATWD.

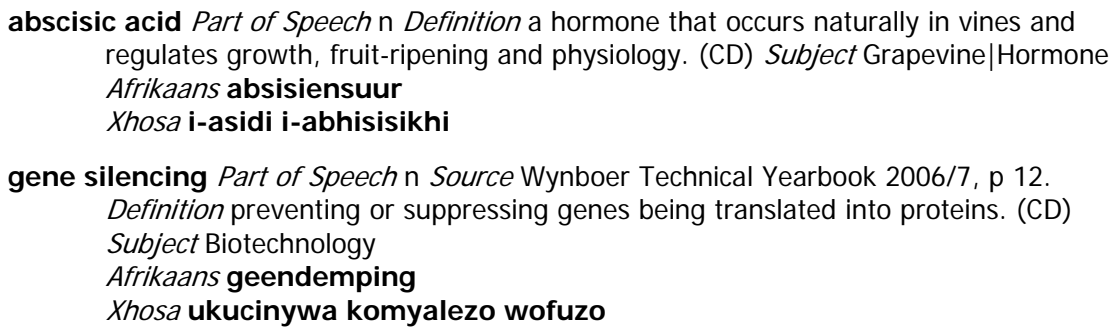

abscisic acid Part of Speech n Definition a hormone that occurs naturally in vines and regulates growth, fruit-ripening and physiology. (CD) Subject Grapevine|Hormone Afrikaans absisiensuur Xhosa i-asidi i-abhisisikhi

gene silencing Part of Speech n Source Wynboer Technical Yearbook 2006/7, p 12. Definition preventing or suppressing genes being translated into proteins. (CD) Subject Biotechnology Afrikaans geendemping Xhosa ukucinywa komyalezo wofuzo

The SATWD is designed for the following user situations:

(a) text reception in English,

(b) text production in English,

(c) translation from English into Afrikaans, and

(d) translation from English into isiXhosa.

A list of translational equivalents for Afrikaans and isiXhosa terms will be provided and the following user situations can occur:

(e) translation from Afrikaans into English,

(f) translation from Afrikaans into isiXhosa,

(g) translation from isiXhosa into Afrikaans, and

(h) translation from isiXhosa into English.

In the South African context, there is a resemblance between the SATWD and A Glossary of Soil Science, published in 1990 (second edition 1995) by the Soil Science Society of South Africa. In this specialised dictionary, translational equivalents and definitions are presented, with the dictionary fulfilling a text reception as well as a translational role. The difference between the two dictionaries is that the SATWD provides explanatory sections only in English, leaving the user with limited lexicographic treatment of a term in isiXhosa and Afrikaans. This is not the ideal situation, also from a pedagogical point of view where mother-tongue knowledge transfer is more advantageous to the user. Hopefully it would be possible to include explanatory sections in Afrikaans and isiXhosa at a later stage of the project in order to ensure text reception in these languages as well.

In the near future, the wine industry plans the Foresight Project and the SATWD could form part of the information system provided. The purpose of the Foresight Project (Spies 2007) is 
establishing an interactive IT-based information platform at SAWIS to develop a 'Vinipedia' in line with the highly successful global Wikipedia interactive internet service. This would be a learning information search design where the best minds make contributions in specific subject areas. It evolves and improves with the contributions of professionals - becoming ever more legitimate as a search engine for initial inquiries. Such a South African 'Vinipedia' could form the basis for a strategic overview service that is always up to date - professional and legitimate.

If the SATWD becomes part of the Foresight Project, more possibilities for text reception could open to users. The outer texts in the Foresight Project could be consulted to gain information on terms used in the dictionary, for example more information on viticulture or oenology. It could serve as an extension of the dictionary, supplying more data to the user to enable text reception. An example of text reception would be a user collecting data on the topic of vine diseases or wine tasting terms.

\section{Labels, from vine to wine}

In compiling the SATWD, the presumed needs of the different user-groups were kept in mind and a handy device, the use of subject labels, was designed to assist users to ensure maximum transfer of information. According to Gouws and Prinsloo (2005: 129), lexicographic labels are frequently used in the comment of semantics to give explicit contextual guidance. They distinguish between subject field labels, stylistic labels and chronolectic labels.

In the case of the SATWD, a whole set of subject-field labels was chosen to assist the user in the transfer of semantic information. As the majority of targetusers could be viewed as semi-experts, they would need considerable guidance to understand terms fully and completely. A large variety of subject-field labels are used to indicate usage within a semantic network.

During the planning stage of the dictionary, a hyponymous relationship was created between labels, for example viticulture: grapevine disease. A term like root plague is placed in a broader semantic field, namely viticulture. The field was then narrowed down by stating that the term forms part of a subdivision grapevine disease. After consultation with subject-field experts, the labelling system was slightly changed.

It is assumed that a term would either belong to one of the two subfields, viticulture and oenology to be lemmatised in the SATWD. According to subject-field specialists, it would be a repetition to state, for example, that grapevine disease falls under viticulture, thus labelling root plague with viticulture: grapevine disease. Instead it was opted to use only the label grapevine disease.

Since the scope of the subject fields viticulture and oenology are so vast, they have been divided into smaller fields more readily to make transfer of information. Under the field of viticulture, one would find subfields such as cultivar, cultivation practice, equipment, fertilization, grapevine deficiency, grapevine 
disease, grapevine morphology, grapevine pest, grapevine physiology and growth regulator, while under the field of oenology, one would find subfields such as barrel size, bottle size, cooperage, distillation, varietal wine, wine aroma wheel, wine fault, wine-making, wine region and wine style. If a term belongs to more than one subfield, both of the subfield labels were used to indicate such a relation, as in the case of 2, 4,6-trichloroanisol where a relation to both wine fault and wine making is shown.

2,4,6-trichloroanisol Part of Speech n Abbreviation TCA Definition a chemical compound which is responsible for the wine being corked (wine fault). (CD) Subject Wine fault/Wine making

Afrikaans 2,4,6-trichloranisool

Xhosa itrirhloranisoli-2,4,6

In the SATWD, terms relating to subject fields other than viticulture and oenology have also been included. The criteria applied were that whenever a term is used in viticulture or oenology, it would be recorded in the dictionary. Subject fields such as biochemistry, biotechnology, botany, chemistry, genetics, law, marketing, microbiology, plant pathology and soil science were added. Terms in these related fields have been labelled accordingly, ensuring successful information transfer. If there is overlapping between different subject fields where a term belongs to both fields, it is indicated with the use of the appropriate subject labels. In the case of bud three subject labels were used to show a relation to botany, grapevine anatomy and viticulture.

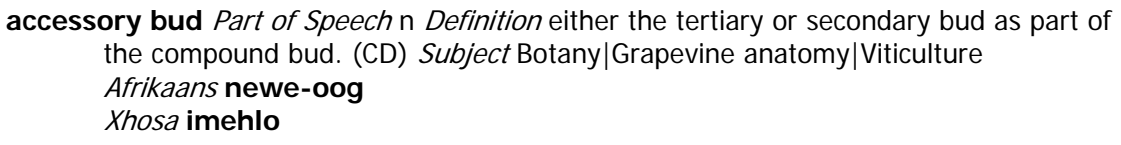

As many terms as possible were labelled in order to help the user with sufficient information transfer, trying to present a bigger semantic picture for the user. To know under which subject field or subfield a term falls, could be of great benefit to a user trying to understand a specific term. A broader semantic insight could subsequently help the user with better text reception and text production.

\section{Proscriptiveness}

The aim of the SATWD is to provide information on the subject fields of viticulture and oenology, as well as linguistic information on terms. During the compilation of the dictionary, one of the challenges posed to the lexicographer was how to deal with the notion of prescriptiveness versus descriptiveness. In a dictionary with a prescriptive point of view, the lexicographer would present the only 'correct' term or translation according to his/her research or findings and a specific linguistic variant can be prohibited. In a dictionary with a 
descriptive point of view, the lexicographer would give all possible terms and translations according to his/her research and findings and it would be left to the user to choose which term or variant to use.

In the case of the SATWD, there is a need to leave it to the user to choose from the given terms, but the dictionary must provide him/her with sufficient information to make an appropriate choice. The lexicographer should ask what would benefit the user most. If the dictionary is to be a practical instrument for the user, it would have to fulfil the function of container of knowledge knowledge of the world and of language. There is a continuous tension between the use of some terms by subject experts and wine industry bodies and the way ordinary users perceive meanings and use words. In order to deal with this, the lexicographer can fulfil the role of a mediator by assisting users in the choice of an appropriate term. In the SATWD, a term would be presented with an editing note indicating whether it is the term preferred by the wine industry or not. The lexicographer could recommend using another term or provide another term reflecting the real language usage of ordinary language speakers. This method could be seen as 'proscriptive'. According to Bergenholtz (2003: 77), proscription entails the presentation of information on language use and assistance with the choice of the correct variant from more than one possibility: 'In practice proscription would be a selective description. Unlike description where every single case is invented individually and described on its own, proscription throughout compares similar cases systematically and makes the same decisions in each case.'

The wine industry has imposed restrictions on the use of certain terms. In the 1973 Wine Dictionary, the term keg was used. Since then it was superseded by the word barrel which the wine industry prefers to use instead of cask, although linguistically there is no difference between the two terms. Another example of such a restriction is the word variety which is not used by the wine industry, the preference being for cultivar.

In many cases, ordinary wine drinkers are unaware of restrictions imposed on certain terms by the wine industry. In the case of boxed wine, the wine industry refers to a specific packaging method, translated as tapvat in Afrikaans. However, in many cases ordinary users would refer to it as bokswyn. There is a difference in register between the two terms, with bokswyn being the informal term. Ordinary wine drinkers also attach the meaning of a lesser quality wine to the term bokswyn. Naturally the wine industry would be very aware of the notion of quality as demonstrated by the use of certain terms. In the case of bulk wine, the wine industry prefers the use of grootmaat instead of stortmaat, which has a connotation of lesser quality. The term drinking wine (drinkwyn in Afrikaans) which was used in the wine industry in official documents during 2002-2005, has been replaced by wine, but there are still ordinary wine drinkers referring to wine in this way. In marketing circles, it is fashionable to use the term handcrafted wine on wine labels, but according to the wine industry no such term officially exists. It would then be the duty of the lexico- 
grapher to ensure sound transfer of information to the user and, since the term occurs in texts, account for it in the dictionary.

Owing to the specific political environment in South Africa, sensitivity has developed around the use of certain words. In the case of the wine industry, one of these words is dopstelsel which describes the infamous way in which some farm labourers on wine farms were remunerated years ago. Although the wine industry is sensitive to the word because of its political connotations and the feelings it can arouse, the word was included in the SATWD. As it is referred to in many documents of the wine industry, it would be to the benefit of the user that the word is defined.

dop system Part of Speech n Definition the illegal system of giving inferior wine to Cape coloured vineyard and cellar workers in partial lieu of wages. (CD)

Afrikaans dopstelsel Xhosa uhlawulo ngotywala

It was decided, however, not to include boys' wine (volkswyn in Afrikaans), referring to an inferior wine, since the word is no longer in use. Because it is not based on historical principles, the SATWD does not include historical words.

Another restriction on terms in the wine industry would be one imposed on South Africa by the European Union. According to the EU, the word champagne, for example, may only occur on a wine etiquette if the content of the bottle was made according to the Champagne method used in France. In South Africa, a similar method is used, but it is called 'Cap Classique'. Champagne made according to the Cap Classique method is more expensive. One would therefore rather find more sparkling wine on the South African market. Sparkling wine is not made according to the Cap Classique method and is not of the same quality. Many users would not know the difference between champagne and sparkling wine, incorrectly using the term champagne for sparkling wine. In this case, the lexicographer could present information proscriptively by including the term champagne in the dictionary and providing it with an editorial note, explaining the situation to the user, but also recognising the application of the word by ordinary users.

\section{Conclusion}

The SATWD was planned with a specific user group in mind who could consult the dictionary in different user situations for different functions. One of the advantages is the on-line accessibility of the dictionary. It is the vision of the compilers of the dictionary that it should become a practical, handy tool for the user, be that person a member of the wine industry, or just an ordinary winedrinker. 


\section{References}

\section{Dictionaries}

Kaufmann, U. and H. Bergenholtz (Eds.). 1998. Encyclopedic Dictionary of Gene Technology. Volume 1: English (with Spanish Equivalents). Volume 2: Spanish (with English Equivalents). Toronto: Lugus Libros.

Hanekom, A.J. (Ed.). 1958. Vertalende en verklarende woordeboek vir die wolbedryf. Engels-Afrikaans. Met verklarings in Afrikaans. Pretoria: South African Wool Board.

Sanderson, K.W. (Ed.). 1990. Directory of Cotton Terms for Southern Africa/Handleiding van katoenterme vir Suidelike Afrika. Pretoria: South African Cotton Board.

Terminology Section, Language Services Bureau in Collaboration with the Oenological and Viticultural Research Institute. 1973. Wine Dictionary (including Viticulture, Winemaking, Wine Chemistry)/Wynwoordeboek (insluitende wingerdbou, wynbereiding, wynkunde). Pretoria: Department of National Education.

Van der Watt, H.v.H. and T.H. van Rooyen. 1990. A Glossary of Soil Science. Pretoria: The Soil Science Society of South Africa.

\section{Other sources}

Bergenholtz, H. and U. Kaufmann. 1997. Terminography and Lexicography. A Critical Survey of Dictionaries from a Single Specialised Field. Tarp, S. (Ed.). 1997. Specialised Lexicography and Terminology. Hermes, Journal of Linguistics 18: 91-125.

Bergenholtz, H. 2003. User-orientated Understanding of Descriptive, Proscriptive and Prescriptive Lexicography. Lexikos 13: 65-80.

Brochet, F. and D. Dubourdieu. 2001. Wine Descriptive Language Supports Cognitive Specificity of Chemical Senses. Brain and Language 77: 187-196.

Gouws, R.H. and D.J. Prinsloo. 2005. Principles and Practice of South African Lexicography. Stellenbosch: SUN PReSS.

Spies, P.H. 2007. South African Wine Industry Business Foresight Project: Framework for the Design of a Wine Industry Foresight and Business Intelligence Service. Available in the SAWIS Industry Library.

Tarp, S. 2005. The Pedagogical Dimension of the Well-conceived Specialised Dictionary. Iberica 10: 7-21. 